\title{
Bone Morphogenetic Protein-2 and -4 Play Tumor Suppressive Roles in Human Diffuse-Type Gastric Carcinoma
}

\author{
Yo-taro Shirai, ${ }^{*}$ Shogo Ehata, ${ }^{*}$ \\ Masakazu Yashiro, ${ }^{\dagger}$ Kazuyoshi Yanagihara, ${ }^{\ddagger}$ \\ Kosei Hirakawa, ${ }^{\dagger}$ and Kohei Miyazono* \\ From the Department of Molecular Pathology,* Graduate School \\ of Medicine, University of Tokyo, Tokyo; the Department of \\ Surgical Oncology, ${ }^{\dagger}$ Graduate School of Medicine, Osaka City \\ University, Osaka; and the Laboratory of Molecular Cell Biology, ${ }^{\ddagger}$ \\ Department of Life Sciences, Yasuda Women's University Faculty \\ of Pharmacy, Hiroshima, Japan
}

A relationship exists between defects in bone morphogenetic protein (BMP) signaling and formation of hamartoma and adenoma in the gastric epithelium; however, the role of BMP signaling in the progression of diffuse-type gastric carcinoma remains unknown. We investigated whether BMP functions as a tumor suppressor in human diffuse-type gastric carcinoma using three different human diffuse-type gastric carcinoma cell lines (OCUM-12, HSC-39, and OCUM2MLN). Overexpression of the dominant-negative form of BMP-2/4-specific type I receptor (ALK-3) in OCUM-12 and HSC-39 cells accelerated their growth $i n$ vivo. BMP-4 induced cell cycle arrest in these cells via p21 induction through the SMAD pathway. Moreover, overexpression of the constitutively active form of ALK-3 in HSC-39 and OCUM-2MLN cells suppressed the proliferation of these cells in vitro and in vivo. Our findings suggest that BMP-2 and BMP-4 function as potent tumor suppressors in diffuse-type gastric carcinoma. (Am J Pathol 2011, 179:2920-2930; DOI: 10.1016/j.ajpath.2011.08.022)

Gastric cancer is the fourth most common cancer and the second most common cause of death from cancer in the world. ${ }^{1}$ According to the Lauren classification, gastric cancer is divided mainly into intestinal and diffuse pathological types. ${ }^{2}$ A major decline has been reported in the incidence and mortality of intestinal-type gastric carcinoma. Eradication of Helicobacter pylori infection, which is the most important environmental risk factor of intestinal- type gastric carcinoma, prevents the development of intestinal-type gastric carcinoma and so contributes to the decrease in its incidence. ${ }^{3}$ On the other hand, the number of patients with diffuse-type gastric carcinoma has been increasing, particularly in the West. ${ }^{4}$ In a majority of cases, diffuse-type gastric carcinoma is diagnosed in advanced stages, with rapid progression and poor prognosis.

Transforming growth factor beta (TGF)- $\beta$, a multifunctional cytokine, exerts growth-inhibitory effects on many types of cells, and is well known as a tumor suppressor during the early stages of carcinogenesis. ${ }^{5}$ Resistance to the growth-inhibitory activity of TGF- $\beta$ often results in cancer development. ${ }^{6}$ In certain types of cancers, including colon cancer, pancreatic cancer, and gastric cancer, defects are observed in the TGF- $\beta$ signal transduction pathways. $^{5,6}$

The role of bone morphogenetic proteins (BMPs) in cancer development and progression remains controversial. Although BMPs were originally identified as molecules that induce ectopic bone formation, BMPs exhibit a broad spectrum of biological activities in various tissues. $^{7,8}$ BMPs promote progression of breast and lung cancers, ${ }^{9,10}$ and in this context specific inhibitors of BMP signaling, such as dorsomorphin, may be useful. ${ }^{11}$ In contrast, however, the findings of several studies indicate that BMP acts as a tumor suppressor in some types of cancers (eg, brain cancer, prostate cancer, and colorec-

\footnotetext{
Supported by KAKENHI (grant-in-aid for scientific research on Innovative Area Integrative Research on Cancer Microenvironment Network; 22112002); by the Global COE program (Integrative Life Science Based on the Study of Biosignaling Mechanisms) from the Ministry of Education, Culture, Sports, Science, and Technology of Japan; by Specific Research Grant from the Takeda Science Foundation (K.M.); by KAKENHI (grantin-aid for Young Scientists; 22700876) from the Japan Society for the Promotion of Science (S.E.)

Accepted for publication August 29, 2011.

Supplemental material for this article can be found at http://ajp. amjpathol.org or at doi: 10.1016/j.ajpath.2011.08.022

Address reprint requests to Kohei Miyazono, M.D., Department of Molecular Pathology, University of Tokyo, 7-3-1 Hongo, Bunkyo-ku, Tokyo 113-0033, Japan. E-mail: miyazono@m.u-tokyo.ac.jp.
} 
tal cancer). ${ }^{12-14}$ Recent studies have revealed that BMP signaling contributes to the suppression of hamartoma and adenoma formation in the gastric epithelium. ${ }^{15,16}$ However, the role of BMP signaling in the development and progression of diffuse-type gastric carcinoma has not been fully investigated.

BMPs can be classified into several subgroups: the BMP-2/4 group, the osteogenic protein 1 (OP-1) group (BMP-5/6/7/8), the growth and differentiation factor 5,6 , and 7 group (GDF-5/6/7), and the BMP-9/10 group. ${ }^{8}$ BMPs bind to two different types of serine-threonine kinase receptors, type I and type II receptors. Activin receptor-like kinases ALK-1, ALK-2, ALK-3, and ALK-6 function as BMP type I receptors; the activin receptors ACTR-IIA and ACTR-IIB and the BMP receptor type 2 (BMPR-II) serve as BMP type II receptors. BMP-2 and BMP-4 bind preferentially to ALK-3 and ALK-6, whereas BMP-6 and BMP-7 bind strongly to ALK-2 and weakly to ALK-6. BMP-9 and BMP-10 bind to ALK-1 and ALK-2. On ligand binding, two type I receptors and two type II receptors form a heteromeric complex, which, in turn, transduces intracellular signals by phosphorylating BMPspecific receptor-regulated SMADs (R-SMADs), SMAD1/ 5/8. Phosphorylated BMP-specific R-SMADs form a heteromeric SMAD complex with common-partner SMAD (co-SMAD), SMAD4. This SMAD complex translocates into the nucleus and regulates transcription of various target genes. In addition to the SMAD pathway, nonSMAD pathways, including mitogen-activated protein kinase (MAPK) pathways, are activated by BMPs and may play important roles in cell proliferation and differentiation. ${ }^{17}$

Kim et $\mathrm{al}^{18}$ reported that loss of expression of SMAD4 is frequently found in diffuse-type gastric carcinoma. Because SMAD4 is shared by TGF- $\beta$ and BMP signaling pathways, loss of SMAD4 expression leads to perturbation of both pathways. The role of TGF- $\beta$ signaling in diffuse-type gastric carcinoma has been well characterized, ${ }^{19-21}$ and it is worth examining whether perturbation of BMP signaling also contributes to the development of diffuse-type gastric carcinoma. We investigated the role of BMP signaling in the progression of diffuse-type gastric carcinoma using human gastric cancer cells established from signet-ring cell carcinoma and from poorly differentiated adenocarcinoma. We present here, for the first time, evidence that BMP-2 and BMP-4 suppress proliferation of diffuse-type gastric carcinoma cells through induction of p21 (p21 WAF1/CIP1) and function as potent tumor suppressors in this type of gastric carcinoma.

\section{Materials and Methods}

\section{Cell Culture and Reagents}

Human diffuse-type gastric carcinoma OCUM-12 and OCUM-2MLN cells were established as described previously. ${ }^{22,23}$ OCUM-2MLN cells were cultured as described previously, ${ }^{24}$ and OCUM-12 cells were cultured under the same conditions. Human diffuse-type gastric carcinoma HSC-39 cells were established as described previously. ${ }^{25}$ HSC-39 cells were cultured in RPMI-1640 medium (Invitrogen, Carlsbad, CA) containing 10\% fetal bovine serum, penicillin $(50 \mathrm{U} / \mathrm{mL})$, and streptomycin (50 $\mu \mathrm{g} / \mathrm{mL}$ ). All cells were grown in a $5 \% \mathrm{CO}_{2}$ atmosphere at $37^{\circ} \mathrm{C}$. BMP-4, BMP-6, and BMP-9 (R\&D Systems, Minneapolis, MN) were used at a concentration of $30 \mathrm{ng} / \mathrm{mL}$. TGF- $\beta 1$ (R\&D Systems) was used at a concentration of 1 $\mathrm{ng} / \mathrm{mL}$. Dorsomorphin (Sigma-Aldrich, St. Louis, MO) was dissolved in dimethyl sulfoxide and used at a concentration of $3 \mu \mathrm{mol} / \mathrm{L}$. Doxycycline was obtained from Clontech (Mountain View, CA).

\section{Lentiviral Production and Infection}

We used a lentiviral vector system to establish diffusetype gastric carcinoma cells stably expressing green fluorescent protein (GFP), the dominant-negative form of ALK-3 (dnALK3), and the constitutively active form of ALK-3 (caALK3). A lentiviral vector encoding GFP (CSCDF-CG-PRE; a gift from Dr. Hiroyuki Miyoshi, RIKEN) was used as the control. cDNAs encoding ALK-3 that lacks the intracellular domain with a carboxyl-terminal HA (influenza hemagglutinin) epitope tag or ALK3QD with a carboxyl-terminal FLAG epitope tag were inserted into the lentiviral vector CSII-EF-RfA. cDNAs encoding caALK3 with a carboxyl-terminal HA epitope tag or Aequorea coerulescens GFP (AcGFP) were inserted into a Tet-ON lentivector (CSIV-TRE-RfA-CMV-KT; a gift from Dr. Hiroyuki Miyoshi). Lentivirus was produced basically as described previously ${ }^{26}$ and was concentrated using Lenti-X concentrator (Clontech) to infect OCUM-12 and HSC-39 cells. HSC-39-Tc-AcGFP or HSC-39-Tc-caALK3 cells were established by isolating Kusabira Orange-expressing cells with semi-limiting dilution.

\section{RNA Isolation and RT-PCR}

Total RNAs were extracted using Isogen reagent (Nippon Gene, Tokyo, Japan) or an RNeasy mini kit (Qiagen, Valencia, CA). First-strand CDNA synthesis, semiquantitative RT-PCR, and quantitative real-time RTPCR were performed as described previously, ${ }^{27}$ with primer sequences as listed in Table 1. Semi-quantitative RT-PCR conditions were as follows: 25 to 40 cycles of $94^{\circ} \mathrm{C}(15 \mathrm{~s}), 55$ to $60^{\circ} \mathrm{C}(30 \mathrm{~s})$, and $68^{\circ} \mathrm{C}$ (1 minute). Values obtained in quantitative real-time RT-PCR were normalized to ACTB (encoding $\beta$-actin).

\section{Immunoblotting}

Immunoblotting was performed as described previously. ${ }^{19}$ Cultured cells were lysed in a buffer containing $20 \mathrm{mmol} / \mathrm{L} \mathrm{Tris-HCl}$ (pH 7.5), $150 \mathrm{mmol} / \mathrm{L} \mathrm{NaCl}, 1 \%$ Nonidet P-40 surfactant, and 1\% aprotinin (Calbiochem). We used antibodies to phospho-Smad1 (Ser463/465)/Smad5 (Ser463/465)/Smad8 (Ser426/428) (pSmad1/5/8; Cell Signaling Technology, Danvers, MA), phospho-Smad2 (Ser465/467) (pSmad2; Zymed Laboratories, South San Francisco, CA), Smad1 (Cell Signaling Technology), Smad2/3 (Cell Signaling Technology), Smad4 (Santa Cruz Biotechnology, Santa Cruz, CA), p21 (BD Biosci- 
Table 1. Primers Used in RT-PCR

\begin{tabular}{|c|c|c|}
\hline Gene & Forward primer & Reverse primer \\
\hline \multicolumn{3}{|c|}{ Semi-quantitative RT-PCR } \\
\hline ACVRL1 & 5'-СTCTACGACTTTCTGCAGAG-3' & $5^{\prime}$-CCACTTGTAGGACTCAAAGC-3' \\
\hline ACVR1 & $5^{\prime}$-ATGTCTTTTAGCCTGCCTGCTG-3' & $5^{\prime}$-ATCAAGCTGATTGGTGCTCTGG-3' \\
\hline$B M P R 1 A$ & $5^{\prime}-$ TGATTTGGAACAGGATGAAGC-3' & $5^{\prime}-$ TGTAGCACATTTCAGGAAGTC-3' \\
\hline TGFBR1 & 5'-TCGCCCTTTTATTTCAGAGGGTACT-3' & 5'-ACAGCAAGTTCCATTCTTCTTTACC-3' \\
\hline$B M P R 1 B$ & $5^{\prime}-$ GCAGCACAGACGGATATTGT $-3^{\prime}$ & $5^{\prime}-T_{T C A T G C C T C A T C A A C A C T-3^{\prime}}$ \\
\hline ACVR2A & 5'-GCAAAATGAATACGAAGTCTA-3' & 5'-GCACCCTCTAATACCTCTGGA-3' \\
\hline$A C V R 2 B$ & $5^{\prime}$-ACACGGGAGTGCATCTACTACAACG-3' & $5^{\prime}$-TCATGAGCTGGGCCTTCCAGA-3' \\
\hline BMPR2 & $5^{\prime}$-CTGCACAGTGTGCTGAGGAAAG-3' & 5'-TGAACTGCCCTGTTACTGCCA-3' \\
\hline TGFBR2 & $5^{\prime}-$ ATAAGGCCAAGCTGAAGCAG-3' & 5'-CTTCTGGAGCCATGTATCTTG-3' \\
\hline SMAD1 & $5^{\prime}-$ TGCCACTCAACGCCACTTTT-3' & 5' -TCATAAGCAACCGCCTGAACAT- $3^{\prime}$ \\
\hline SMAD2 & $5^{\prime}-$ CCCATCGAAAAGGATTGCCACA-3' & $5^{\prime}$-TGCATGGAAGGTTTCTCCAACC-3' \\
\hline SMAD3 & 5'-GGACGACTACAGCCATTCCA-3' & 5'-TTCCGATGTGTCTCCGTGTCA-3' \\
\hline SMAD4 & 5'-CTTTGAAATGGATGTTCAG-3' & 5'-CATCCTGATAAGGTTAAGGG-3' \\
\hline SMAD5 & 5'-ACGTCAATGGCCAGCTTGTT-3' & 5' -TCCAACGGCTTTAGCTCATGA-3' \\
\hline SMAD8 & 5'-ATCTTTGTGCAGAGCCGGAA-3' & 5' -TCCTGGCGATGATACTCAGCA-3' \\
\hline BMP2 & $5^{\prime}-$ CCAGAAACGAGTGGGAAAAC - $3^{\prime}$ & $5^{\prime}-$ AAGTCCACGTACAAAGGGTG-3' \\
\hline BMP4 & $5^{\prime}-$ ACTGGTCCACCACAATGTGACACG-3' & $5^{\prime}$-GCTGAAGTCCACATAGAGCGAGTG-3' \\
\hline ACTB & $5^{\prime}-$ TCACCCACACTGTGCCCATCTACGA-3' & $5^{\prime}$ - CAGCGGAACCGCTCATTGCCAATGG-3' \\
\hline \multicolumn{3}{|c|}{ Quantitative real-time RT-PCR } \\
\hline ID3 & 5'-GACTTCACCAAATCCCTTCC-3' & $5^{\prime}-$ ССАСТССТТССАСАССТС-3' \\
\hline CDKN1A & 5'-AGTGGACAGCGAGCAGCTGA-3' & 5'-CGAAGTTCCATCGCTCACGG-3' \\
\hline CDKN1B & 5'-CGGTGGACCACGAAGAGTTAA-3' & 5'-GGCTCGCCTCTTCCATGTC-3' \\
\hline CDKN2A & 5'-TGCCTTTTCACTGTGTTGGAGTT-3' & $5^{\prime}-$ TCGCAAGAAATGCCCACAT-3' \\
\hline$C D K N 2 B$ & 5'-CCGCCCACAACGACTTTATT-3' & 5'-CAGCCTTCATCGAATTAGGTG-3' \\
\hline CDC25A & $5^{\prime}-$ GCCTGTCACCAACCTGAC-3' & $5^{\prime}$-CCAGGAGAATCTAGACAGAAACC-3' \\
\hline MYC & 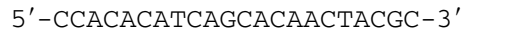 & 5'-CGGTTGTTGCTGATCTGTCTCA-3' \\
\hline SMAD4 & 5'-GATACGTGGACCCTTCTGGA-3' & 5'-ACCTTTGCCTATGTGCAACC-3' \\
\hline ACTB & $5^{\prime}$-TCACCCACACTGTGCCCATCTACGA-3' & $5^{\prime}$-CAGCGGAACCGCTCATTGCCAATGG-3' \\
\hline
\end{tabular}

ences, San Jose, $C A$ ), retinoblastoma protein (RB; $B D$ Biosciences), poly(ADP-ribose) polymerase (PARP; Cell Signaling Technology), GFP (MBL International, Woburn, MA), HA (3F10; Roche, Basel, Switzerland), FLAG (M2, Sigma-Aldrich), and $\alpha$-tubulin (Sigma-Aldrich).

\section{RNA Interference and Oligonucleotides}

RNA interference was performed as described previously. ${ }^{21}$ Stealth small interfering RNA (siRNA) duplex oligoribonucleotides against human SMAD4 (siRNA/SMAD4) or non-targeting control (siRNA/NTC) were synthesized by Invitrogen. OCUM-12 cells were transfected with each siRNA according to the manufacturer's protocols. Short hairpin RNA (shRNA) constructs against human p21 were designed using BLOCK-it RNAi Designer (Invitrogen), with the target sequence 5'-GCCTCTGGCATTAGAATTATT-3'.

\section{Immunocytochemistry}

Before seeding cells, we used a poly-L-lysine solution (Sigma-Aldrich) to coat the chamber plates. Cells $(2.5 \times$ $10^{4}$ cells) were seeded in eight-well chamber plates. On the next day, cells were treated with BMP-4. Cells were fixed in $3.7 \%$ formaldehyde and then permeabilized with PBS containing $0.1 \%$ Triton $X-100$ surfactant. A mouse monoclonal antibody against human Ki-67 (MIB-1; DakoCytomation, Carpinteria, CA) and Alexa Fluor 488-conjugated mouse secondary antibody (Invitrogen) were used to detect proliferating cells. The nuclei were counterstained with TOTO-3 fluorophore (Invitrogen). Fluores- cence was examined using a Zeiss LSM 510 Meta confocal microscope and was measured with LSM Image Browser software version 3.5.0.359 (Carl Zeiss Microlmaging, Göttingen, Germany). Quantification was performed by counting Alexa Fluor 488-positive cells against TOTO3-positive cells in five fields.

\section{Flow Cytometry}

Cells were dissociated into single-cell populations and labeled with propidium iodide using a Cycletest Plus DNA Reagent Kit (BD Biosciences). Cell cycle distribution of cells was determined using an EPICS XL flow cytometer with EXPO32 ADC software (Beckman Coulter, Life Sciences, Indianapolis, IN). FlowJo software version 7.2.5 (Tree Star, Ashland, OR) was used to generate histograms.

\section{Cell Proliferation Assay}

Cells $\left(0.5 \times 10^{4}\right.$ to $1.5 \times 10^{4}$ cells $)$ were seeded in triplicate in 12-well plates. On the next day, cells were treated with BMP-4. Cells were counted with a hemocytometer.

\section{Subcutaneous Xenograft Mode/s}

BALB/c nu/nu male mice (4 to 5 weeks of age) were obtained from the Oriental Yeast Company (Tokyo, Japan). A total of $5 \times 10^{6}$ cells in $100 \mu \mathrm{L}$ of culture medium were injected into the right flank of each mouse, unless 


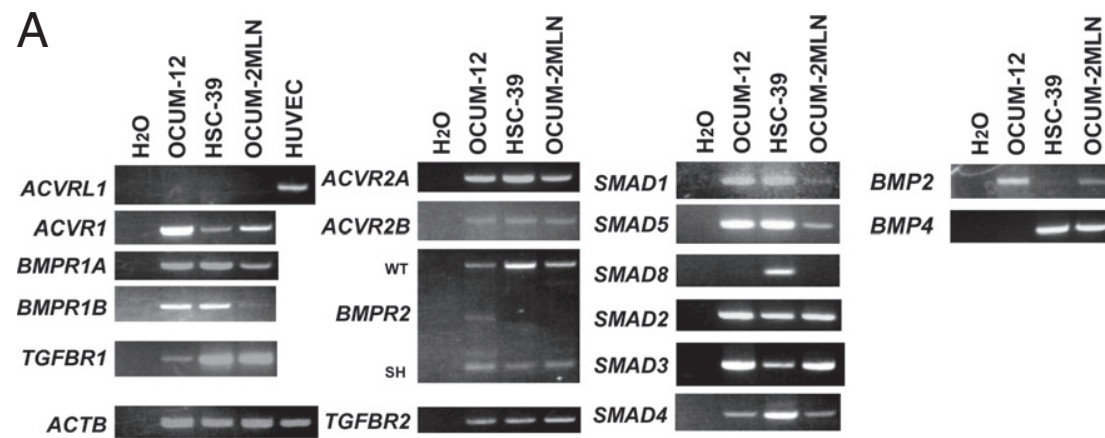

Figure 1. BMP-4 signals are transduced in diffusetype gastric carcinoma cells. A: Expression of BMP and TGF- $\beta$ signal components in OCUM-12 cells, HSC-39 cells, and OCUM-2MLN cells was analyzed by semiquantitative RT-PCR. Human umbilical vein endothelia cells (HUVECs) were used as positive control for ACVRL1. Two alternatively spliced forms of BMPR2 were detected: the wild-type form (WT) and a short form (SH). B: Diffuse-type gastric carcinoma cells were treated with BMP-4, BMP-6, BMP-9, TGF- $\beta 1$, or dorsomorphin for 1 hour. Cell lysates were subjected to immunoblotting with antibodies, as indicated under Materials and Methods. C: Diffuse-type gastric carcinoma cells were treated with BMP-4 or dorsomorphin for 2 hours. Expression of ID3 mRNA was determined by quantitative real-time RT-PCR. Data are presented as means \pm SD.
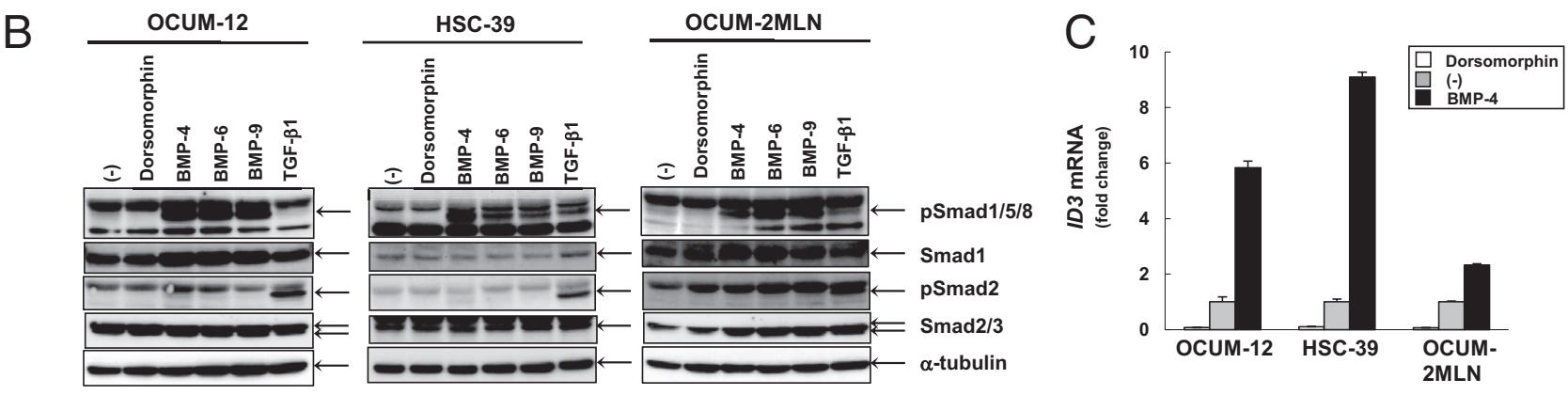

otherwise mentioned. Subcutaneous tumors were measured externally, and tumor volume was estimated as described previously. ${ }^{19}$ All animal experiments were performed in accordance with the policies of the Animal Ethics Committee, University of Tokyo.

\section{Immunohistochemistry}

Formalin-fixed, paraffin-embedded gastric tissues were obtained from patients with diffuse-type gastric carcinoma at the Osaka City University Hospital, Osaka, Japan, with informed consent. H\&E staining of tissues was performed as described previously. ${ }^{19}$ Antigen retrieval was performed with $10 \mathrm{mmol} / \mathrm{L}$ sodium citrate $(\mathrm{pH} \mathrm{6.0)}$ at $121^{\circ} \mathrm{C}$ for 10 minutes, and sections were immunostained with primary antibodies (pSmad1/5/8, p21, and MIB-1) and biotinylated secondary antibodies. Immunodetection was performed with a Vectastain ABC Kit (Vector Laboratories, Burlingame, CA) and 3,3'-diaminobenzidine (DakoCytomation). Sections were weakly counterstained with hematoxylin. All studies were conducted using protocols approved by the Osaka City University Ethics Committee.

\section{Statistical Analysis}

The size of tumors was analyzed statistically by repeatedmeasures analysis of variance. Tukey-Kramer post hoc tests were used for examining differences between multiple groups. Two-tailed Student's $t$-tests were used to compare two groups. Results were considered to be statistically significant at $P<0.05$.

\section{Results}

\section{BMP Signals Are Transduced in Diffuse-Type Gastric Carcinoma Cells}

We first evaluated the expressions of BMP signal components in OCUM-12, HSC-39, and OCUM-2MLN cells using semi-quantitative RT-PCR (Figure 1A). In these cells, BMP type I receptor genes ACVR1 (encoding ALK2), BMPR1A (encoding ALK-3), and BMPR1B (encoding ALK-6) were expressed; ACVRL1 (encoding ALK-1), which is mainly expressed in endothelial cells and transduces BMP-9 signaling, was not expressed. BMP type II receptor genes $A C V R 2 A$ (encoding ACTR-IIA), ACVR2B (encoding ACTR-IIB), and BMPR2 were also expressed in these cells. We detected expression of SMAD4 transcripts in these cells. Among the three types of BMPspecific R-SMADs, SMAD1 and SMAD5 were expressed in all these cells, whereas SMAD8 was expressed only in HSC-39 cells. We also detected expression of BMP2 and/or BMP4 in all these cells. Expression levels of BMPR1B, SMAD1, and SMAD5 in OCUM-2MLN cells were lower than those in the other diffuse-type gastric carcinoma cells. Of the TGF- $\beta$ signal components, TGFBR1 (TGF- $\beta$ type I receptor, encoding ALK-5) and TGFBR2 (TGF- $\beta$ type II receptor, encoding TGF- $\beta$ receptor type $2, \mathrm{~T} \beta \mathrm{R}-\mathrm{II}$ ) were expressed in these cells, as well as two TGF- $\beta$-specific R-SMADs, SMAD2 and SMAD3.

We next examined phosphorylation of SMAD1/5/8 in OCUM-12, HSC-39, and OCUM-2MLN cells by immunoblotting (Figure 1B). In these cells, SMAD1/5/8 were phosphorylated by BMP-4 (in the BMP-2/4 group), which was suppressed by the small-molecule BMP 
inhibitor dorsomorphin. ${ }^{11}$ In addition, phosphorylation of SMAD $1 / 5 / 8$ was induced by BMP-6 and BMP-9, whereas phosphorylation of SMAD2 was induced only by TGF- $\beta 1$. Phosphorylation of SMAD1/5/8 was also induced by TGF- $\beta 1$ in HSC-39 cells, as shown in certain other cells. ${ }^{28}$ We also evaluated the expression of ID3 mRNA, one of the downstream targets of BMP-4, in these cells using quantitative real-time RT-PCR (Figure 1C). As expected, BMP-4 induced the expression of ID3 in these cells and dorsomorphin suppressed it, although the degrees of increased expression of ID3 by BMP-4 varied.

\section{In Vivo Tumor Growth of Diffuse-Type Gastric Carcinoma Cells Is Accelerated by Disruption of BMP Signaling}

To determine whether BMP signaling is responsible for the regulation of tumor growth of diffuse-type gastric carcinoma cells in vivo, we used diffuse-type gastric carcinoma cells stably expressing dnALK3 (OCUM-12dnALK3 and HSC-39-dnALK3) (Figure 2A). BMP-4-induced expression of pSMAD1/5/8 in dnALK3-expressing cells was lower than that in the control GFP-expressing cells (OCUM-12-GFP and HSC-39-GFP). We also confirmed that the expression of dnALK3 had little effect on TGF- $\beta$ signaling in diffuse-type gastric carcinoma cells (Figure 2B). Induction of ID3 mRNA by BMP-4 was suppressed in dnALK3-expressing cells (Figure $2 \mathrm{C}$ ), indicating that BMP-2/4 signaling in these cells was successfully inhibited.

We next xenografted GFP- and dnALK3-expressing cancer cells into BALB/c nude mice. We found that in vivo tumor growth of OCUM-12-dnALK3 or HSC-39-dnALK3 cells was significantly more accelerated than that of the corresponding control cells (OCUM-12-GFP or HSC-39GFP; Figure 2D). TGF- $\beta$ signaling was reported to regulate the vascular density and fibrosis in diffuse-type gastric carcinoma cells. ${ }^{19,20}$ We therefore also examined the histology of the resultant tumor tissues by H\&E staining. The appearance of the microenvironment in tumor tissues, including angiogenesis and fibrosis, was not obviously affected by the expression of dnALK3 (data not shown).

\section{BMP-4 Arrests the Cell Cycle of Diffuse-Type Gastric Carcinoma Cells}

We next evaluated the effects of BMP-4 on proliferation and apoptosis of diffuse-type gastric carcinoma cells in vitro. The in vitro proliferation of OCUM-12-GFP and HSC39-GFP cells was inhibited by treatment with BMP-4, and growth inhibition by BMP-4 was abrogated in OCUM-12dnALK3 and HSC-39-dnALK3 cells (Figure 3A). Because BMPs have been reported to induce apoptosis of certain types of cancer cells, ${ }^{29,30}$ induction of apoptosis by BMP-4 in OCUM-12 and HSC-39 cells was examined. However, cleavage of PARP in these cells was not enhanced by BMP-4 (Figure 3B). Moreover, TUNEL staining
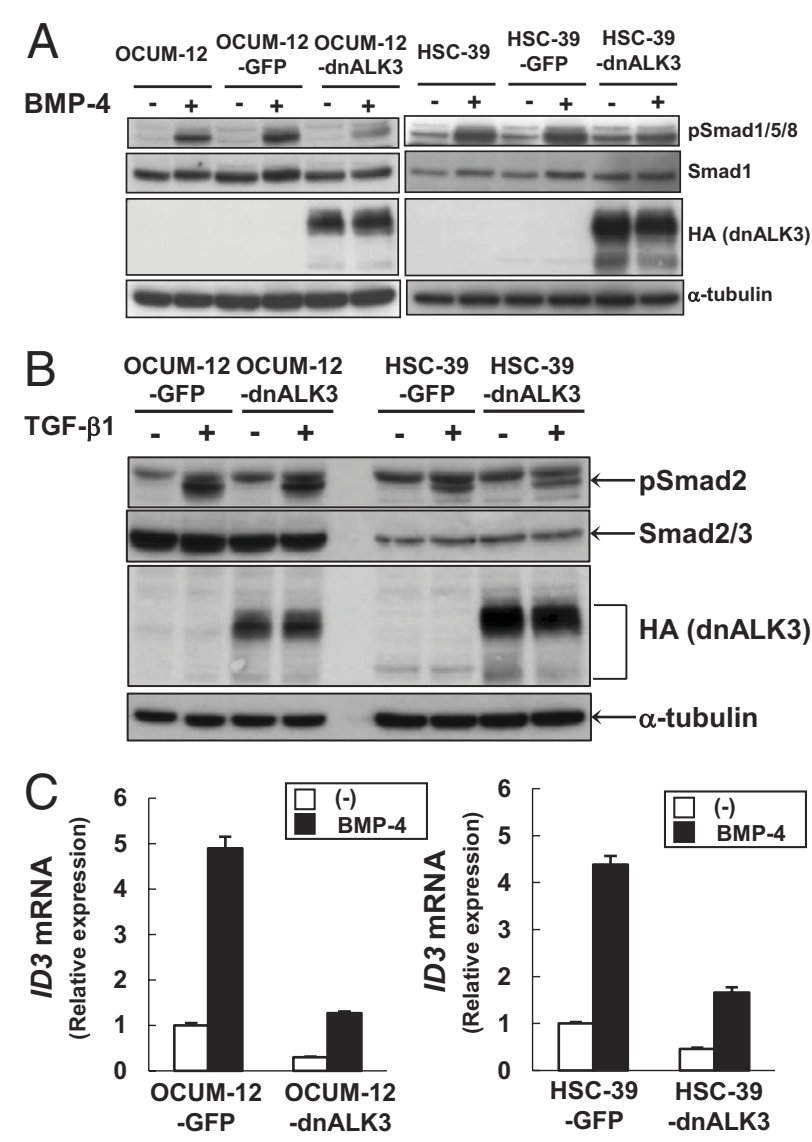

D
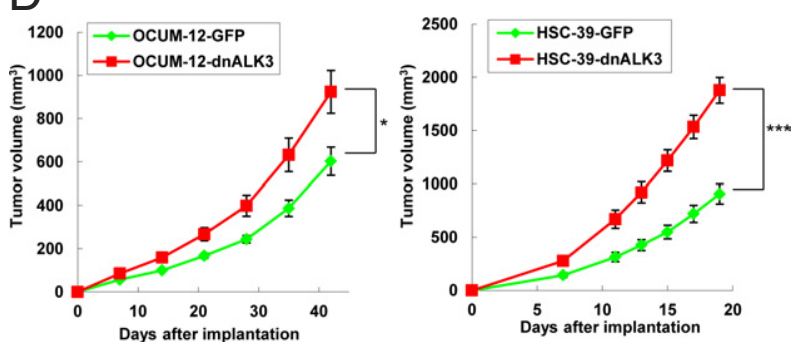

Figure 2. In vivo tumor growth of diffuse-type gastric carcinoma cells is accelerated by the expression of dnALK3. A: Diffuse-type gastric carcinoma cells were infected with lentivirus carrying GFP CDNA (OCUM-12-GFP and HSC-39-GFP) or HA-tagged dnALK3CDNA (OCUM-12-dnALK3 and HSC-39dnALK3). Parental cells and infected cells were treated with BMP-4 for 1 hour. Cell lysates were subjected to immunoblotting with antibodies, as indicated under Materials and Methods. B: Diffuse-type gastric carcinoma cells expressing GFP or dnALK3 were treated with TGF- $\beta 1$ for 1 hour. Cell lysates were subjected to immunoblotting with antibodies, as indicated under Materials and Methods. C: Diffuse-type gastric carcinoma cells expressing GFP or dnALK3 were treated with BMP-4 for 24 hours. Expression of ID3 mRNA was determined by quantitative real-time RT-PCR. Data are presented as means \pm SD. D: Diffuse-type gastric carcinoma cells expressing GFP or dnALK3 were subcutaneously xenografted into BALB/c $n u / m u$ mice (OCUM12-GFP, $n=7$; OCUM-12-dnALK3, $n=9$; HSC-39-GFP, $n=7$; HSC-39dnALK3, $n=8$ ). Quantification of tumor volume over time (OCUM-12, day 0 to day 42 ; HSC-39, day 0 to day 19) are shown. Data are presented as means $\pm \mathrm{SE} .{ }^{*} P<0.05 ;{ }^{* * * *} P<0.001$.

revealed that BMP-4 did not induce DNA fragmentation in OCUM-12 cells (see Supplemental Figure S1 at $h t t p: / /$ ajp.amjpathol.org).

Recent reports also suggest that BMPs negatively regulate cell cycle progression of cancer cells, including intestinal-type gastric carcinoma cells and prostate 

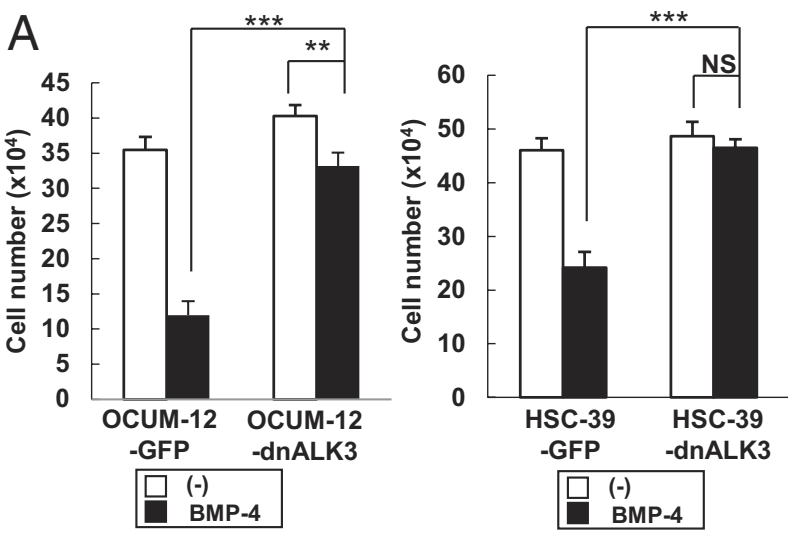

B

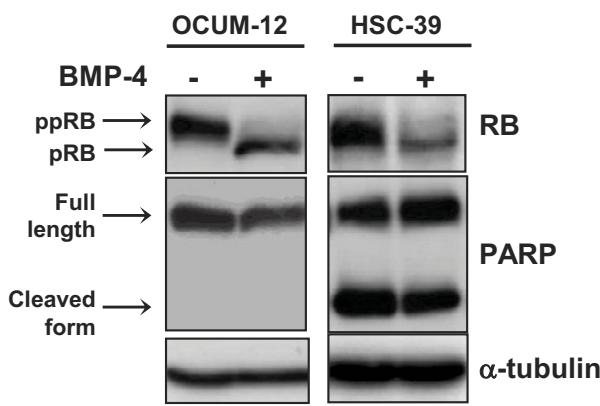

C

$(-)$
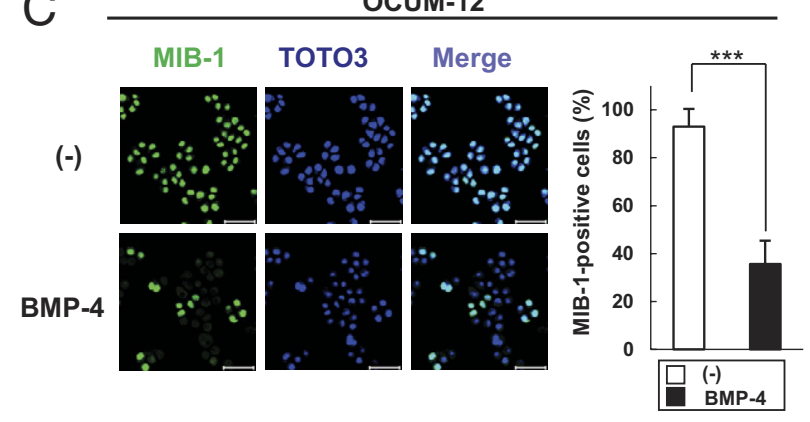

OCUM-12

$\mathrm{D}$

OCUM-12
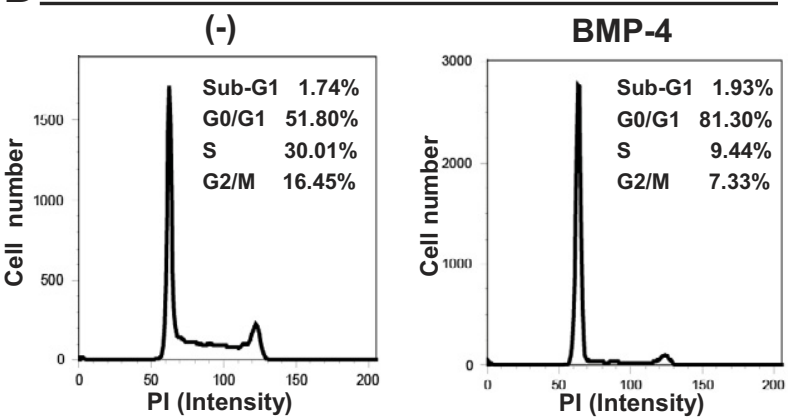

Figure 3. BMP-4 arrests the cell cycle of diffuse-type gastric carcinoma cells. A: Diffuse-type gastric carcinoma cells expressing GFP or dnALK3 were treated with BMP- 4 for 4 days, and cell numbers were counted. Data are presented as means $\pm \mathrm{SD} .{ }^{* * * *} P<0.01 ;{ }^{* * * * *} P<0.001$. B: Diffuse-type gastric carcinoma cells were treated with BMP- 4 for 24 hours (OCUM-12) or 48 hours (HSC-39). Cell lysates were subjected to immunoblotting with antibodies, as indicated under Materials and Methods. Note hyperphosphorylated and underphosphorylated forms of $\mathrm{RB}$ (ppRB and $\mathrm{pRB}$ ) and full-length and cleaved form of PARP (arrows). C: MIB-1 immunostaining of OCUM-12 cells at 48 hours after BMP- 4 treatment. Representative images and the relative cell numbers of MIB-1-positive cells are shown. Scale bars: $50 \mu \mathrm{m}$. Data are presented as means $\pm \mathrm{SD}$. ${ }^{* * * *} P<0.001$. D: Cell cycle analysis of OCUM-12 cells at 48 hours after BMP- 4 treatment using flow cytometry. PI, propidium iodide. cancer cells. ${ }^{13,31}$ We therefore further examined the effect of BMP-4 on cell cycle progression of OCUM-12 and HSC-39 cells. Treatment of these cells with BMP-4 decreased the hyperphosphorylated form of RB (ppRB), which promotes the transition from $\mathrm{G} 1$ to $\mathrm{S}$ phase of the cell cycle (Figure 3B). In addition, human Ki-67 (MIB-1) immunostaining revealed that the number of MIB-1-positive OCUM-12 cells was decreased in the presence of BMP-4 (Figure 3C). Flow cytometry also revealed that treatment of OCUM-12 cells with BMP-4 resulted in a lower number of cells in $S$ and G2/M phases and a higher number of cells in G0/G1 phase (Figure 3D).

\section{BMP-4 Induces p21 Expression in Diffuse-Type Gastric Carcinoma Cells through the SMAD Pathway}

To further investigate the mechanism by which BMP-4 negatively regulates the cell cycle of diffuse-type gastric carcinoma cells, we examined the expression levels of cyclin-dependent kinase (CDK) inhibitors by quantitative real-time RT-PCR (see Supplemental Figure S2 at http:// ajp.amjpathol.org). Among the CDK inhibitors examined, the expression of CDKN1B (encoding p27) was not affected by BMP-4, and no expression of CDKN2A (encoding p16) and $C D K N 2 B$ (encoding p15) was detected in OCUM-12 and HSC-39 cells. The proto-oncogene MYC was transiently up-regulated by BMP-4 in HSC-39 cells, but no effect was seen in OCUM-12 cells. Down-regulation of CDC25A (cell division cycle 25A) by BMP-4 was observed only in OCUM-12 cells. Thus, up-regulation of CDKN1A (encoding p21) mRNA by BMP-4 was commonly observed in these cells in a time-dependent manner (Figure 4A). Moreover, neither increase in p21 protein nor decrease in ppRB by BMP-4 was noted in dnALK3expressing cells, but both were present in control GFPexpressing cells (Figure 4B).

Next, we attempted to identify the signaling pathways mediating the regulation of $\mathrm{p} 21$ in the presence of BMP-4 in diffuse-type gastric carcinoma cells. To evaluate whether the SMAD pathway is involved in the BMP-4mediated induction of p21, we knocked down the endogenous expression of SMAD4 in OCUM-12 cells by transfection with siRNA targeting SMAD4. BMP-4-mediated induction of CDKN1A mRNA and p21 protein was dramatically abolished in SMAD4-silenced cells (Figure 4, C and D).

\section{The Inhibitory Effect of BMP-4 on the Growth of Diffuse-Type Gastric Carcinoma Cells Is Mediated in Part by Induction of p21}

To determine whether the BMP-4-mediated induction of p21 is responsible for the growth arrest of diffusetype gastric carcinoma cells, we established OCUM-12 and HSC-39 cells stably expressing a shRNA construct against p21 (OCUM-12-shRNA/p21 and HSC-39shRNA/p21) with a lentiviral vector system. The expression of CDKN1A mRNA and p21 protein was success- 

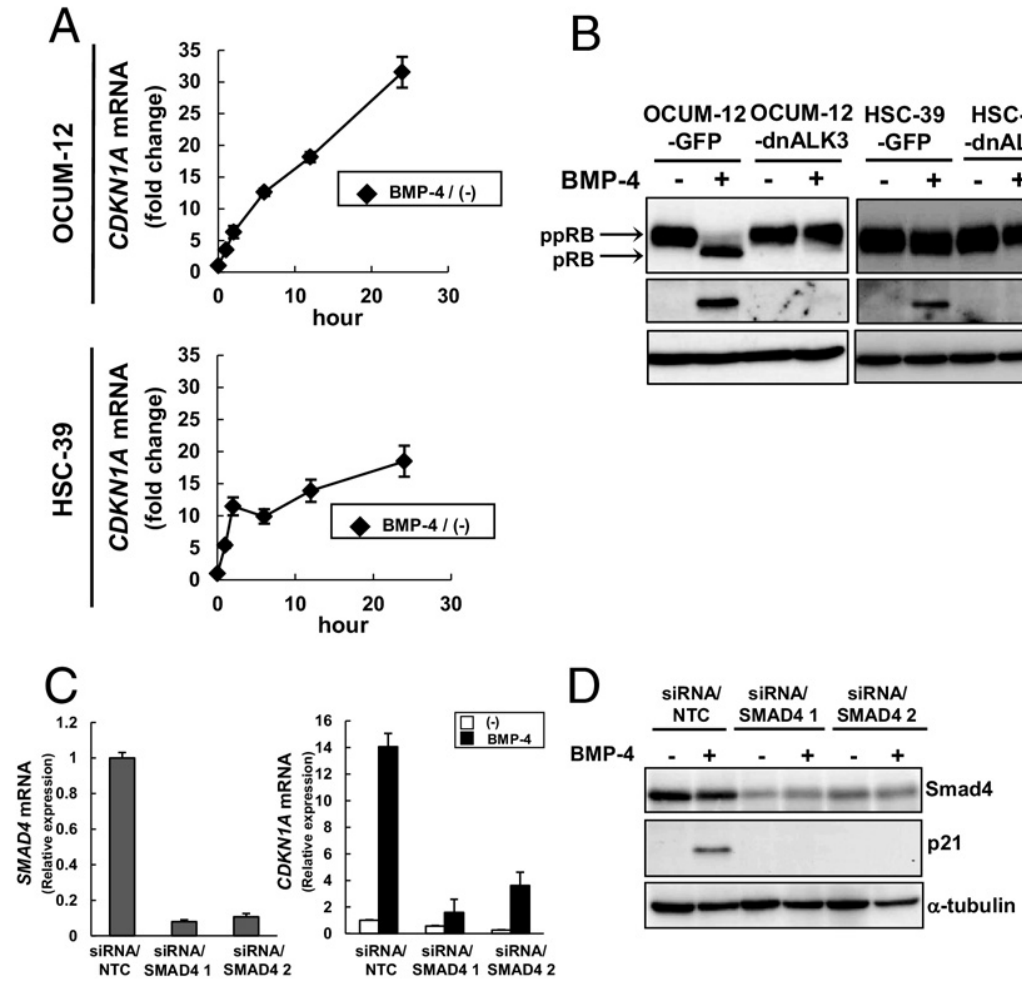

B

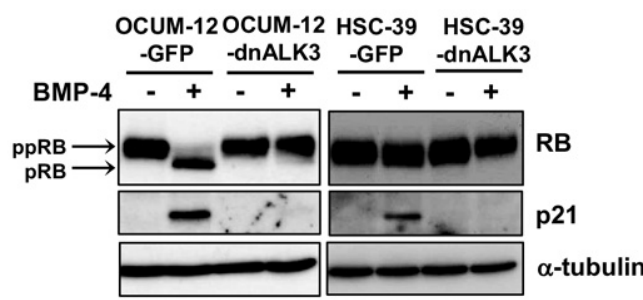

Figure 4. BMP-4 regulates the expression of CDKN1A in OCUM-12 cells through the SMAD pathway. A: Diffuse-type gastric carcinoma cells were treated with BMP-4 for 1 to 24 hours. Expression of $C D K N 1 A$ mRNA was determined by quantitative real-time RT-PCR data are presented as fold change under BMP-4 stimulation (means + SD). B: Diffusetype gastric carcinoma cells expressing GFP or dnALK3 were treated with BMP-4 for 24 hours (OCUM-12) or 72 hours (HSC-39). Cell lysates were subjected to immunoblotting with antibodies, as indicated under Materials and Methods. Note ppRB and pRB (arrows). C: OCUM-12 cells were transfected with either siRNA/NTC or SiRNA/SMAD4 and then were treated with BMP- 4 for 24 hours. Expression levels of SMAD4 mRNA and CDKN1A mRNA were determined by quantitative realtime RT-PCR. Data are presented as means \pm SD. D: The cell lysates in $\mathbf{C}$ were subjected to immunoblotting with antibodies, as indicated under Materials and Methods. fully knocked down in OCUM-12-shRNA/p21 and HSC39-shRNA/p21 cells in the absence or presence of BMP-4, but not in control cells expressing the nontargeting control shRNA construct (OCUM-12-shRNA/ NTC and HSC-39-shRNA/NTC) (Figure 5, A and B). The in vitro cell proliferation assay revealed attenuated growth inhibition of OCUM-12-shRNA/p21 and HSC39-shRNA/p21 cells by BMP-4, compared with that of OCUM-12-shRNA/NTC and HSC-39-shRNA/NTC cells, respectively (Figure $5 \mathrm{C}$ ). In accord with this finding, the decrease in ppRB in the presence of BMP-4 was almost absent in OCUM-12-shRNA/p21 cells (Figure 5B).

\section{The Expression of caALK3 Inhibits the Growth of Diffuse-Type Gastric Carcinoma Cells}

Next, we attempted to prove that the tumor growth of diffuse-type gastric carcinoma cells is diminished by activating ALK-3 signaling with Tet-On system. HSC-39 cells stably expressing tetracycline-inducible (Tc) caALK3 (HSC-39-Tc-caALK3) or control AcGFP (HSC39-Tc-AcGFP) were established. Phosphorylation of SMAD1/5/8 and induction of ID3 mRNA, CDKN1A mRNA, and p21 protein were observed in HSC-39-Tc-CaALK3 cells by treatment with doxycycline (see Supplemental
A

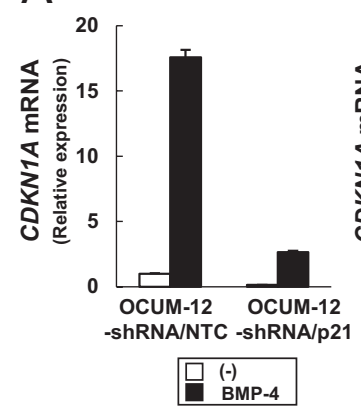

B

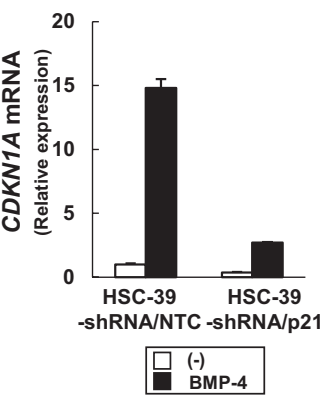

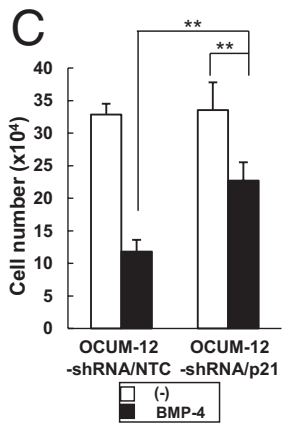

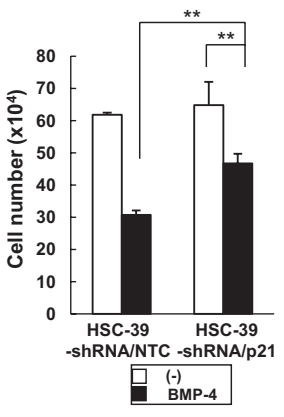

Figure 5. The inhibitory effect of BMP-4 on the growth of diffuse-type gastric carcinoma cells is mediated by induction of p 21 . A: OCUM-12 and HSC-39 cells were infected with lentivirus carrying a shRNA construct against p21 (OCUM-12-shRNA/p21 and HSC-39-shRNA/p21) or a control shRNA construct (OCUM-12shRNA/NTC and HSC-39-shRNA/NTC). Infected cells were treated with BMP-4 for 24 hours. Expression of CDKN1A mRNA was determined by quantitative real-time RT-PCR. Data are presented as means \pm SD. B: Infected OCUM-12 cells were treated with BMP-4 for 24 hours. Cell lysates were subjected to immunoblotting with antibodies, as indicated under Materials and Methods. Note ppRB and pRB (arrows). C: Numbers of infected OCUM-12 and HSC-39 cells were counted at 4 days after treatment with BMP-4. Data are presented as means \pm SD. ${ }^{* *} P<0.01$ 
Figure S3, A and B, at http://ajp.amjpathol.org), suggesting that ALK-3 signaling was successfully activated in HSC-39-TC-caALK3 cells by doxycycline. We found that proliferation of HSC-39-Tc-caALK3 cells was strongly inhibited by doxycycline (see Supplemental Figure S3C at http://ajp.amjpathol.org). The effect of caALK3 on in vivo tumor growth was also examined in a mouse xenograft model. In vivo tumor growth of HSC-39-TC-CaALK3 cells was also severely reduced compared with that of HSC39-Tc-AcGFP cells (see Supplemental Figure S3D at http://ajp.amjpathol.org). Contrary to our expectation, however, tumor growth of HSC-39-Tc-caALK3 cells was suppressed even in the absence of doxycycline, suggesting that the expression of caALK3 might be induced without doxycycline treatment in vivo.

We also tried to introduce caALK3 into another diffusetype gastric carcinoma cell line, OCUM-2MLN, without using the Tet-On system. OCUM-2MLN cells expressed lower levels of certain BMP signal components than did HSC-39 cells (Figure 1A), and OCUM-2MLN cells were less sensitive to exogenous BMP-4 (Figure 1C). Phosphorylation of SMAD1/5/8 and expression of target genes of BMP-4 were enhanced in OCUM-2MLN-caALK3 cells, even in the absence of BMP-4 (Figure 6, A-C). Results from the mouse xenograft model indicated that activated ALK-3 signaling diminished the size of tumors of OCUM$2 \mathrm{MLN}$ cells (Figure 6D). Thus, activation of ALK-3 signaling inhibits in vitro proliferation of HSC-39 cells and in vivo tumor growth of HSC-39 and OCUM-2MLN cells.

\section{Phosphorylation of SMAD1/5/8 Is Associated with Expression of p21 and Ki-67 in Gastric Epithelial Tissues}

Finally, we evaluated the correlation between BMP signaling and proliferation of gastric epithelial cells using human gastric tissues. Samples of normal gastric epithelium and intestinal metaplasia, a possible precursor lesion in the development of gastric carcinoma, were stained with anti-pSmad1/5/8 antibody, anti-p21 antibody, and MIB-1 (see Supplemental Figure S4 at $h t t p: / /$ ajp.amjpathol.org). In these tissues, strong staining for pSMAD 1/5/8 was detected mainly in the nuclei of surface epithelial cells located in the gastric pit. The majority of cells positive for pSMAD1/5/8 coexpressed p21 in their nuclei, suggesting that phosphorylation of SMAD1/5/8 may positively correlate with the expression of p21. Conversely, MIB1-positive Ki-67-expressing cells were not frequently observed in cells positive for PSMAD 1/5/8 and for p21 in these tissues. MIB-1-positive cells were distributed mainly in the lower parts of the gastric pit, where weak or negative staining for pSMAD $1 / 5 / 8$ was frequently observed.

\section{Discussion}

Diffuse-type gastric carcinoma is characterized by thick fibrosis, which may be induced by TGF- $\beta$ secreted by cancer-associated fibroblasts and/or cancer cells. TGF- $\beta$ is reported to be involved in the pathogenesis of diffusetype gastric carcinoma. ${ }^{32}$ We previously showed that
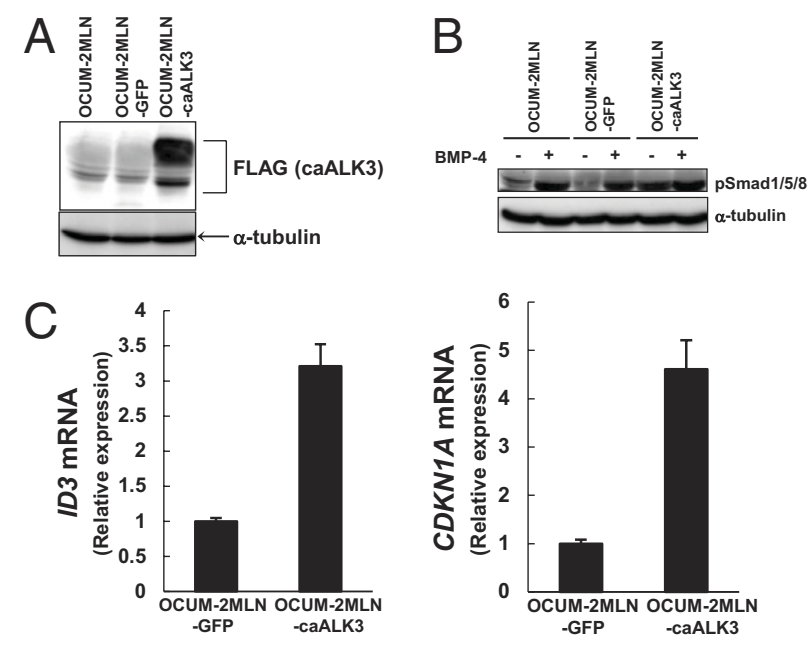

$D$
$E$

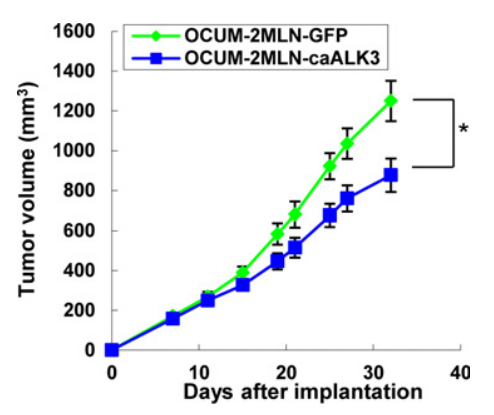

$E$

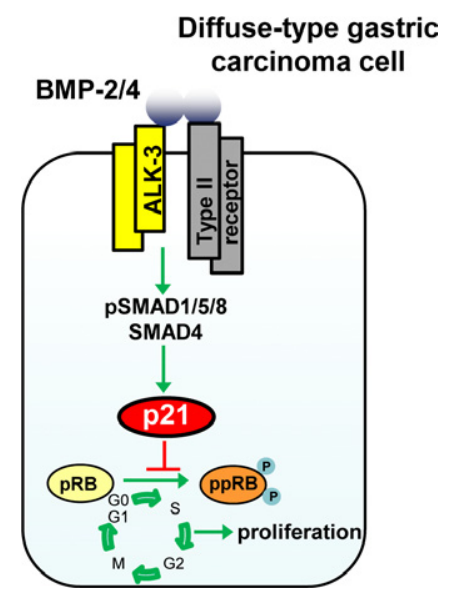

Figure 6. The expression of caALK3 inhibits growth of diffuse-type gastric carcinoma cells in vivo. A: OCUM-2MLN cells were infected with lentivirus carrying GFP CDNA (OCUM-2MLN-GFP) or FLAG-tagged caALK3 cDNA (OCUM-2MLN-caALK3). Cell lysates were subjected to immunoblotting with antibodies, as indicated under Materials and Methods. B: Infected OCUM2 MLN cells were treated with BMP-4 for 1 hour. Cell lysates were subjected to immunoblotting with antibodies, as indicated under Materials and Methods. C: The expression levels of ID3 and CDKN1A mRNA in infected OCUM$2 \mathrm{MLN}$ cells were determined by quantitative real-time RT-PCR. Data are presented as means \pm SD. D: Infected OCUM-2MLN cells were subcutaneously xenografted into BALB/c $n u / n u$ mice (OCUM-2MLN-GFP, $n=7$; OCUM-2MLN-caALK3, $n=8$ ). Quantification of tumor volume over time (day 0 to day 32) are shown. Data are presented as means \pm SE. ${ }^{*} P<0.05$. E: Schematic representation of BMP signaling pathway negatively regulating proliferation of diffuse-type gastric carcinoma cells via induction of p21 through the SMAD pathway.

disruption of TGF- $\beta$ signaling in diffuse-type gastric carcinoma cells results in acceleration of their growth with alteration of the tumor microenvironment via down-regulation of thrombospondin 1 (TSP1) and tissue inhibitor of 
metalloproteinase 2 (TIMP2). ${ }^{19,20}$ Recently, we also demonstrated that TGF- $\beta$ diminishes cancer-initiating cells within diffuse-type gastric carcinoma. ${ }^{21}$ These findings suggest that TGF- $\beta$ negatively regulates the progression of diffuse-type gastric carcinoma in vivo. Although TGF- $\beta$ is well known for its tumor-suppressive role in the early phase of cancer progression, the role of BMPs in cancer progression is not fully understood. In the present study, we examined the role of BMP signaling in the progression of diffuse-type gastric carcinoma, using three different human diffuse-type gastric carcinoma cell lines. We demonstrated that in vivo growth of OCUM-12 and HSC-39 cells is promoted by disruption of BMP-2/4 signaling (Figure 2D); however, disruption of BMP-2/4 signaling in these cancer cells did not obviously alter the histological appearances of xenograft tumors (data not shown). In addition, the regulation of THBS1 (encoding TSP-1) and TIMP2 mRNA by BMP-4 was not commonly observed in OCUM-12 and HSC-39 cells (data not shown), suggesting that BMP-4 suppresses the progression of diffuse-type gastric carcinoma in a mechanism different from that of TGF- $\beta$.

In juvenile polyposis, a cancer predisposition syndrome in the gastrointestinal tract, germline mutations of SMAD4 and BMPR1A were found. ${ }^{33,34}$ Mutations of SMAD4 and BMPR2 were also found in the majority of sporadic colorectal cancers. ${ }^{35}$ On the basis of these observations, BMP is considered to be a tumor suppressor in colorectal cancer. ${ }^{14}$ Recently, the relationship between BMP signaling and gastric carcinogenesis has also been highlighted, and somatic frameshift mutations of BMPR2 were found in $6.5 \%$ of gastric cancers with microsatellite instability. ${ }^{36}$ Bmpr1a conditional knockout mice and Nog (encoding noggin, an extracellular antagonist of BMPs) transgenic mice with activated prostaglandin E2 pathway were reported to develop hamartoma in the gastric epithelium. ${ }^{15,16}$ In addition, BMP signals were reported to regulate the proliferation of gastric epithelial cells in mice. ${ }^{37}$ In the present study, an inverse correlation between phosphorylation of SMAD1/5/8 and expression of Ki-67 was observed in the majority of normal or metaplastic gastric epithelium (see Supplemental Figure S4 at http://ajp.amjpathol.org). These findings suggest that BMP functions as a tumor suppressor in the development and progression of gastric cancer.

BMPs consist of many ligands, including the BMP-2/4, OP-1, GDF-5/6/7, and BMP-9/10 groups. ${ }^{8}$ BMP-2 is required for formation of the gastric gland during development in the chicken embryo and is expressed in the human adult stomach. ${ }^{38,39}$ Lower expression levels of SMAD4 and epigenetic silencing of the BMP2 gene were more frequently found in diffuse-type than in intestinal-type gastric carcinoma. ${ }^{18,40}$ In the present study, we demonstrated that overexpression of dnALK3 in OCUM-12 and HSC-39 cells accelerated their tumor growth (Figure 2D). Moreover, constitutive activation of BMP-4-ALK-3 signaling in HSC-39 and OCUM-2MLN cells increased expression of p21 and suppressed proliferation of these cells in vitro and in vivo (Figure 6; see also Supplemental Figure S3 at $h$ ttp://ajp.amjpathol.org).

The CDK inhibitor p21 is a potent tumor suppressor. Many reports indicate that the expression of p21 nega- tively correlates with the malignant potential or prognosis of gastric cancer. ${ }^{41,42}$ One study, however, showed opposite findings. ${ }^{43}$ Moreover, Ogawa et a ${ }^{41}$ reported that loss of p21 expression was more frequently observed in diffuse-type than in intestinal-type gastric carcinoma. BMP has been shown to induce expression of p21 in several cell types, including cancer cells, aortic smooth muscle cells, and osteoblast-like cells. ${ }^{13,31,44-47}$ Here, we have presented the first evidence that BMP-4-ALK-3 signaling increases the expression of p21. Furthermore, induction of p21 by BMP-4 is crucial for growth inhibition of diffuse-type gastric carcinoma cells in all three diffuse-type gastric carcinoma cell lines examined. These findings suggest that BMP-4-ALK-3 signaling may exert an antiproliferative function in diffuse-type gastric carcinoma via induction of p21 through the SMAD pathway (Figure 6E).

The level of BMP-2 in blood has been associated with disease progression in gastric cancer patients. ${ }^{48,49}$ BMP-2 is also reported to accelerate motility and invasiveness of gastric cancer cells via activation of the phosphoinositide 3-kinase pathway. ${ }^{50}$ These reports suggest that BMP might enhance invasion and metastasis in certain types of gastric cancer. Collectively, BMP-2/4 may function as tumor suppressors in a cell context-dependent manner. In conclusion, we present the evidence that BMP-2/4 suppress the progression of diffuse-type gastric carcinoma. These findings suggest that BMP-2/4 function as potent tumor suppressors in diffuse-type gastric carcinoma via induction of $\mathrm{p} 21$.

\section{Acknowledgments}

We thank Yasuyuki Morishita (University of Tokyo) for technical assistance and thank Dr. Hiroyuki Miyoshi (RIKEN) for the lentiviral vector system.

\section{References}

1. Yaghoobi M, Bijarchi R, Narod SA: Family history and the risk of gastric cancer. Br J Cancer 2010, 102:237-242

2. Lauren $P$ : The two histological main types of gastric carcinoma diffuse and so-called intestinal-type carcinoma. An attempt at a histoclinical classification. Acta Pathol Microbiol Scand 1965, 64:31-49

3. Fukase K, Kato M, Kikuchi S, Inoue K, Uemura N, Okamoto S, Terao S, Amagai K, Hayashi S, Asaka M; Japan Gast Study Group: Effect of eradication of Helicobacter pylori on incidence of metachronous gastric carcinoma after endoscopic resection of early gastric cancer: an open-label, randomised controlled trial. Lancet 2008, 372:392-397

4. Henson DE, Dittus C, Younes M, Nguyen H, Albores-Saavedra J: Differential trends in the intestinal and diffuse types of gastric carcinoma in the United States, 1973-2000: increase in the signet ring cell type. Arch Pathol Lab Med 2004, 128:765-770

5. Ikushima $\mathrm{H}$, Miyazono K: TGFbeta signalling: a complex web in cancer progression. Nat Rev Cancer 2010, 10:415-424

6. Bierie B, Moses HL: Tumour microenvironment: TGFbeta: the molecular Jekyll and Hyde of cancer. Nat Rev Cancer 2006, 6:506-520

7. Suzuki Y, Montagne K, Nishihara A, Watabe T, Miyazono K: BMPs promote proliferation and migration of endothelial cells via stimulation of VEGF-A/VEGFR2 and angiopoietin-1/Tie2 signalling. J Biochem 2008, 143:199-206

8. Miyazono K, Kamiya Y, Morikawa M: Bone morphogenetic protein receptors and signal transduction. J Biochem 2010, 147:35-51

9. Katsuno Y, Hanyu A, Kanda H, Ishikawa Y, Akiyama F, Iwase T, Ogata E, Ehata S, Miyazono K, Imamura T: Bone morphogenetic protein 
signaling enhances invasion and bone metastasis of breast cancer cells through Smad pathway. Oncogene 2008, 27:6322-6333

10. Langenfeld EM, Kong Y, Langenfeld J: Bone morphogenetic protein 2 stimulation of tumor growth involves the activation of Smad-1/5. Oncogene 2006, 25:685-692

11. Yu PB, Hong CC, Sachidanandan C, Babitt JL, Deng DY, Hoyng SA Lin HY, Bloch KD, Peterson RT: Dorsomorphin inhibits BMP signals required for embryogenesis and iron metabolism. Nat Chem Biol 2008, 4:33-41

12. Piccirillo SG, Reynolds BA, Zanetti N, Lamorte G, Binda E, Broggi G, Brem H, Olivi A, Dimeco F, Vescovi AL: Bone morphogenetic proteins inhibit the tumorigenic potential of human brain tumour-initiating cells. Nature 2006, 444:761-765

13. Miyazaki H, Watabe T, Kitamura T, Miyazono K: BMP signals inhibit proliferation and in vivo tumor growth of androgen-insensitive prostate carcinoma cells. Oncogene 2004, 23:9326-9335

14. Hardwick JC, Kodach LL, Offerhaus GJ, van den Brink GR: Bone morphogenetic protein signalling in colorectal cancer. Nat Rev Cancer 2008, 8:806-812

15. Bleuming SA, He XC, Kodach LL, Hardwick JC, Koopman FA, Ten Kate FJ, van Deventer SJ, Hommes DW, Peppelenbosch MP, Offerhaus GJ, Li L, van den Brink GR: Bone morphogenetic protein signaling suppresses tumorigenesis at gastric epithelial transition zones in mice. Cancer Res 2007, 67:8149-8155

16. Oshima $\mathrm{H}$, Itadani $\mathrm{H}$, Kotani $\mathrm{H}$, Taketo MM, Oshima $\mathrm{M}$ : Induction of prostaglandin E2 pathway promotes gastric hamartoma development with suppression of bone morphogenetic protein signaling. Cancer Res 2009, 69:2729-2733

17. Moustakas A, Heldin CH: Non-Smad TGF-beta signals. J Cell Sci 2005, 118:3573-3584

18. Kim JY, Park DY, Kim GH, Choi KU, Lee CH, Huh GY, Sol MY, Song GA, Jeon TY, Kim DH, Sim MS: Smad4 expression in gastric adenoma and adenocarcinoma: frequent loss of expression in diffuse type of gastric adenocarcinoma. Histol Histopathol 2005, 20:543-549

19. Komuro A, Yashiro M, Iwata C, Morishita Y, Johansson E, Matsumoto Y, Watanabe A, Aburatani H, Miyoshi H, Kiyono K, Shirai YT, Suzuk $\mathrm{HI}$, Hirakawa K, Kano MR, Miyazono K: Diffuse-type gastric carcinoma: progression, angiogenesis, and transforming growth factor beta signaling. J Natl Cancer Inst 2009, 101:592-604

20. Johansson E, Komuro A, Iwata C, Hagiwara A, Fuse Y, Watanabe A, Morishita Y, Aburatani H, Funa K, Kano MR, Miyazono K: Exogenous introduction of tissue inhibitor of metalloproteinase 2 reduces accelerated growth of TGF-beta-disrupted diffuse-type gastric carcinoma. Cancer Sci 2010, 101:2398-2403

21. Ehata S, Johansson E, Katayama R, Koike S, Watanabe A, Hoshino Y, Katsuno Y, Komuro A, Koinuma D, Kano MR, Yashiro M, Hirakawa K, Aburatani H, Fujita N, Miyazono K: Transforming growth factor-beta decreases the cancer-initiating cell population within diffuse-type gastric carcinoma cells. Oncogene 2011, 30:1693-1705

22. Fujihara T, Sawada T, Hirakawa K, Chung YS, Yashiro M, Inoue T, Sowa M: Establishment of lymph node metastatic model for human gastric cancer in nude mice and analysis of factors associated with metastasis. Clin Exp Metastasis 1998, 16:389-398

23. Kato Y, Yashiro M, Noda S, Tendo M, Kashiwagi S, Doi Y, Nishii T, Matsuoka J, Fuyuhiro Y, Shinto O, Sawada T, Ohira M, Hirakawa K: Establishment and characterization of a new hypoxia-resistant cancer cell line, OCUM-12/Hypo, derived from a scirrhous gastric carcinoma. Br J Cancer 2010, 102:898-907

24. Nagano Y, Koinuma D, Miyazawa K, Miyazono K: Context-dependent regulation of the expression of $\mathrm{c}$-Ski protein by Arkadia in human cancer cells. J Biochem 2010, 147:545-554

25. Yanagihara K, Seyama T, Tsumuraya M, Kamada N, Yokoro K: Establishment and characterization of human signet ring cell gastric carcinoma cell lines with amplification of the c-myc oncogene. Cancer Res 1991, 51:381-386

26. Ehata S, Hanyu A, Fujime M, Katsuno $Y$, Fukunaga E, Goto K, Ishikawa Y, Nomura K, Yokoo H, Shimizu T, Ogata E, Miyazono K, Shimizu K, Imamura T: Ki26894, a novel transforming growth factorbeta type I receptor kinase inhibitor, inhibits in vitro invasion and in vivo bone metastasis of a human breast cancer cell line. Cancer Sci 2007, 98:127-133

27. Hoshino $Y$, Katsuno $Y$, Ehata S, Miyazono K: Autocrine TGF-beta protects breast cancer cells from apoptosis through reduction of BH3-only protein, Bim. J Biochem 2011, 149:55-65
28. Liu IM, Schilling SH, Knouse KA, Choy L, Derynck R, Wang XF: TGFbeta-stimulated Smad1/5 phosphorylation requires the ALK5 L45 loop and mediates the pro-migratory TGFbeta switch. EMBO J 2009, 28:88-98

29. Kawamura C, Kizaki M, Yamato K, Uchida H, Fukuchi Y, Hattori $Y$, Koseki T, Nishihara T, Ikeda Y: Bone morphogenetic protein-2 induces apoptosis in human myeloma cells with modulation of STAT3. Blood 2000, 96:2005-2011

30. Fukuda N, Saitoh M, Kobayashi N, Miyazono K: Execution of BMP-4induced apoptosis by p53-dependent ER dysfunction in myeloma and B-cell hybridoma cells. Oncogene 2006, 25:3509-3517

31. Wen XZ, Miyake S, Akiyama Y, Yuasa Y: BMP-2 modulates the proliferation and differentiation of normal and cancerous gastric cells. Biochem Biophys Res Commun 2004, 316:100-106

32. Mizoi T, Ohtani H, Miyazono K, Miyazawa M, Matsuno S, Nagura H: Immunoelectron microscopic localization of transforming growth factor beta 1 and latent transforming growth factor beta 1 binding protein in human gastrointestinal carcinomas: qualitative difference between cancer cells and stromal cells. Cancer Res 1993, 53:183-190

33. Howe JR, Roth S, Ringold JC, Summers RW, Jarvinen HJ, Sistonen P, Tomlinson IP, Houlston RS, Bevan S, Mitros FA, Stone EM, Aaltonen LA: Mutations in the SMAD4/DPC4 gene in juvenile polyposis. Science 1998, 280:1086-1088

34. Howe JR, Bair JL, Sayed MG, Anderson ME, Mitros FA, Petersen GM, Velculescu VE, Traverso G, Vogelstein B: Germline mutations of the gene encoding bone morphogenetic protein receptor $1 \mathrm{~A}$ in juvenile polyposis. Nat Genet 2001, 28:184-187

35. Kodach LL, Wiercinska E, de Miranda NF, Bleuming SA, Musler AR, Peppelenbosch MP, Dekker E, van den Brink GR, van Noesel CJ, Morreau H, Hommes DW, Ten Dijke P, Offerhaus GJ, Hardwick JC: The bone morphogenetic protein pathway is inactivated in the majority of sporadic colorectal cancers. Gastroenterology 2008, 134:1332-1341

36. Park SW, Hur SY, Yoo NJ, Lee SH: Somatic frameshift mutations of bone morphogenic protein receptor 2 gene in gastric and colorectal cancers with microsatellite instability. APMIS 2010, 118:824829

37. Shinohara M, Mao M, Keeley TM, El-Zaatari M, Lee HJ, Eaton KA, Samuelson LC, Merchant JL, Goldenring JR, Todisco A: Bone morphogenetic protein signaling regulates gastric epithelial cell development and proliferation in mice. Gastroenterology 2010, 139:20502060.e2

38. van den Brink GR, Hardwick JC, Tytgat GN, Brink MA, Ten Kate FJ, Van Deventer SJ, Peppelenbosch MP: Sonic hedgehog regulates gastric gland morphogenesis in man and mouse. Gastroenterology 2001, 121:317-328

39. Narita T, Saitoh K, Kameda T, Kuroiwa A, Mizutani M, Koike C, Iba H, Yasugi S: BMPs are necessary for stomach gland formation in the chicken embryo: a study using virally induced BMP-2 and Noggin expression. Development 2000, 127:981-988

40. Wen XZ, Akiyama Y, Baylin SB, Yuasa Y: Frequent epigenetic silencing of the bone morphogenetic protein 2 gene through methylation in gastric carcinomas. Oncogene 2006, 25:2666-2673

41. Ogawa M, Maeda K, Onoda N, Chung YS, Sowa M: Loss of p21WAF1/CIP1 expression correlates with disease progression in gastric carcinoma. Br J Cancer 1997, 75:1617-1620

42. Gomyo $\mathrm{Y}$, Ikeda M, Osaki M, Tatebe S, Tsujitani S, Ikeguchi M, Kaibara N, Ito $\mathrm{H}$ : Expression of p21 (waf1/cip1/sdi1), but not p53 protein, is a factor in the survival of patients with advanced gastric carcinoma. Cancer 1997, 79:2067-2072

43. Yasui W, Akama Y, Kuniyasu H, Yokozaki H, Semba S, Shimamoto F, Tahara E: Expression of cyclin-dependent kinase inhibitor p21WAF1/ CIP1 in non-neoplastic mucosa and neoplasia of the stomach: relationship with p53 status and proliferative activity. J Pathol 1996, 180:122-128

44. Pouliot F, Labrie C: Role of Smad1 and Smad4 proteins in the induction of p21WAF1, Cip1 during bone morphogenetic protein-induced growth arrest in human breast cancer cells. J Endocrinol 2002, 172 187-198

45. Franzen A, Heldin NE: BMP-7-induced cell cycle arrest of anaplastic thyroid carcinoma cells via p21(CIP1) and p27(KIP1). Biochem Biophys Res Commun 2001, 285:773-781 
46. Wong GA, Tang V, El-Sabeawy F, Weiss RH: BMP-2 inhibits proliferation of human aortic smooth muscle cells via p21Cip1/Waf1. Am J Physiol Endocrinol Metab 2003, 284:E972-E979

47. Chang SF, Chang TK, Peng HH, Yeh YT, Lee DY, Yeh CR, Zhou J, Cheng CK, Chang CA, Chiu JJ: BMP-4 induction of arrest and differentiation of osteoblast-like cells via p21 CIP1 and p27 KIP1 regulation. Mol Endocrinol 2009, 23:1827-1838

48. Park Y, Kim JW, Kim DS, Kim EB, Park SJ, Park JY, Choi WS, Song JG, Seo HY, Oh SC, Kim BS, Park JJ, Kim YH, Kim JS: The bone morphogenesis protein-2 (BMP-2) is associated with progression to metastatic disease in gastric cancer. Cancer Res Treat 2008 , 40:127-132

49. Park Y, Kang MH, Seo HY, Park JM, Choi CW, Kim YH, Kim IS, Kim JS, Oh SC: Bone morphogenetic protein-2 levels are elevated in the patients with gastric cancer and correlate with disease progression. Med Oncol 2010, 27:1192-1199

50. Kang MH, Kim JS, Seo JE, Oh SC, Yoo YA: BMP2 accelerates the motility and invasiveness of gastric cancer cells via activation of the phosphatidylinositol 3-kinase (PI3K)/Akt pathway. Exp Cell Res 2010, 316:24-37 